\title{
Perjanjian Implementasi (Implementing Agreement) Bab XI Konvensi Hukum Laut 1982
}

\author{
Etty R. Agoes
}

\begin{abstract}
As a result of lengthy negotiations, the 1982 United Nations Convention on the Law of the Sea, was geared toward the fulfilment for a need of a new dimension in the regulation of the international community's uses of the oceans. However as the new law of the sea is a result of a "give and take" process, of a series of accomodation, its implementation is hindered by the argument that its provisions have not given enough accomodation to the existing conditions. Such argument mostly came from the developed countries, in particular to the issue of deep sea-bed mining exploitation. The Implementing Agreement to Part XI of the Convention is a breakthrough to overcome these problems.
\end{abstract}

\section{Pendahuluan}

Konvensi Hukum Laut 1982 yang telah mulai berlaku sejak bulan November 1994 telah mengalami perkembangan dengan diadakannya secara terus-menerus pertemuan lebih lanjut mengenai pelaksanaan Konvensi tersebut melalui pelbagai forum. Seperti diketahui, sebagai kelanjutan dari pelaksanaan Konvensi telah dibentuk antara lain, Intemational Tribunal for the Law of the Sea (ITLOS), Commission on the Limits of the Continental Shelf, dan telah dicapai beberapa perjanjian tambahan, seperti misalnya Perjanjian Implementasi (Implementing Agreement) tahun 1994.

Sampai dengan bulan Oktober 1998, telah dicapai sejumlah 132 ratifikasi, termasuk kedalamnya ratifikasi oleh beberapa negara maju seperti misalnya Federasi Rusia dan Inggris. Selain dari itu juga telah berhasil dipilih dan dilantik 21 orang anggota Commission on the Limits of the Continental Shelf. Di samping sejumlah besar negara-negara berkembang, sampai dengan bulan November 1997 ratifikasi ini telah meliputi juga hampir seluruh negara anggota Masyarakat Eropa, Federasi Rusia, Cina, Jepang, India, Austrália, Brazil dan Argentina.

Di samping itu, dalam hal penambangan di dasar laut samudra dalam (deep sea-bed mining), perjanjian penambangan oleh 'pioneer investor' telah melibatkan juga warganegara AS, negara yang sampai saat ini 
belum meratifikasi Konvensi, melalui beberapa konsorsium perusahaan pertambangan. ${ }^{1}$

Seperti diketahui substansi pengaturan Konvensi Hukum. Laut 1982 meliputi ketentuan-ketentuan tentang pelbagai macam penggunaan laut seperti misalnya pelayaran, serta pembagian hak dan kewajiban antara pengakomodasian kepentingan-kepentingan negara pantai dalam pemanfaatan sumber daya alam di daerah lepas pantainya, dengan perlindungan terhadap kebebasan negaranegara lain untuk menggunakan ruang laut tanpa hambatan-hambatan yang tidak wajar.

Konvensi Hukum Laut 1982. juga mengandung ketentuan-ketentuan yang mengatur tentang penambangan di daerah dasar laut samudra dalam di luar yurisdiksi nasional, beserta kelembagaannya. Seperti diketahui masalah inilah yang untuk pertama kali memicu Majelis Umum PBB untuk mengangkatnya $k e$ dalam agenda persidangannya dan kemudian menghasilkan suatu Resolusi khusus untuk menangani masalah ini beserta kelembagaannya. ${ }^{2}$ Pada akhirnya lembaga yang dibentuk khusus untuk menangani masalah penambangan di dasar laut samudra dalam ini, berubah fungsi menjadi panitia persiapan Konferensi Hukum Laut ke- III.

Pada waktu persidangan Konferensi sudah mencapai hasil tahap akhir Rancangan Konvensi pada sekitar tahun 1980, di AS terjadi perubahan pemerintahan dari Carter yang demokrat ke Reagan sebagai wakil Partai Republik. Hal ini ternyata kemudian juga mempengaruhi keterlibatan AS dalam perundingan tentang pembentukan hukum laut yang baru tersebut, sehingga delegasi AS pada waktu itu merasa perlu untuk memikirkan kembali sikapnya terhadap hasil-hasil perundingan yang telah dicapai. ${ }^{3}$

Pada waktu Konvensi Hukum Laut 1982 siap untuk memperoleh tanda tangan pengesahan dari wakil-wakil negara peserta Konferensi pada bulan Desember 1982, AS tidak termasuk ke dalam negara yang turut membubuhkan tanda tangannya. Pada akhirnya ketika Konvensi Hukum Laut 1982 sudah akan dapat memperoleh kekuatan mengikat dengan adanya ratifikasi ke-60 oleh Guyana pada tahun 1993, AS diikuti oleh negara-negara maju lainnya merasa masih belum dapat menerima isi Konvensi secara keseluruhan. Daiam situasi demikian dapat

'Konvensi Hukum Laut 1982 sebenarnya telah diajukan ke Senat untuk diratifikasi sejak tahun 1994. Meskipun telah mendapat dukungan dari Menteri Luar Negeri Warren Christopher, dan akhir-akhir ini juga didukung oleh Menteri Pertahanan William S. Cohen, Komisi Hubungan Luar Negeri Senat AS masih belum berhasil untuk menyepakati ratifikasi tersebut. Lihat Margaret M. Tomlison. "Recent Development in the International Law of the Sea." Intemational Lawyer. Vol. 32. 1998. Hlm. 600.

2UNGA Res. 2340 (XXII), 18 Desember 1967.

${ }^{3}$ Seperti diketahui Reagan yang berasal dari negara bagian Califomia ini, untuk mencapai kursikepresidenan banyak dibantu secara finansiil oleh perusahaan-perusahaan pertambangan, yang banyak di antaranya tidak dapat menerima hasil yang telah dicapai pada Konferensi tersebut. 
dikatakan bahwa kekuatan mengikat Konvensi Hukum Laut 1982 secara efektif terbatas hanya pada bagian-bagian Konvensi yang tidak menimbulkan permasalahan.

Dalam tulisan ini akan dicoba diuraikan salah satu perkembangan penting tentang implementasi Konvensi Hukum Laut 1982, yaitu dicapainya suatu Perjanjian pada tahun 1994 tentang Pelaksanaan Bab XI Konvensi (Implementing Agreement). ${ }^{4}$

Perjanjian tentang Implementasi Bab XI Konvensi Hukum Laut 1982 (Agreement Relating to the Implementation of Part XI of the 1982 Convention on the Law of the Sea) $)^{5}$

Perjanjian tentang Implementasi Bab Xl Konvensi Hukum Laut 1982 yang mengatur tentang penambangan di dasar laut samudra dalam ini, berhasil dicapai setelah beberapa negara berkembang melakukan inisiatif untuk mengajak AS kembali merundingkan masalah Konvensi Hukum Laut 1982, khususnya tentang bagian yang tidak mendapat dukungan dari AS dan negara-negara maju lainnya, yaitu tentang masalah penambangan dasar laut samudra dalam.

Seperti diketahui, salah satu masalah yang menjadi penghambat turutnya AS dalam perkembangan pencapaian Konvensi Hukum
Laut 1982 di Konferensi PBB tentang Hukum Laut yang ke III adalah keberatan AS pada ketentuan-ketentuan Bab XI yang dianggap lebih menguntungkan negara-negara berkembang, di samping kurang memberikan jaminan bagi keikutsertaan negara-negara industri maju dalam pelbagai lembaga terkait. ${ }^{6}$ Sikap AS ini telah menghambat keinginan negara-negara maju lainnya yang telah menandatangani Konvensi Hukum Laut 1982 tersebut, untuk menindaklanjutinya dengan peratifikasian Konvensi.

Perjanjian ini berisi ketentuan yang menetapkan tidak berlakunya beberapa ketentuan Bab XI Konvensi Hukum Laut 1982 yang berkaitan dengan penambangan daerah dasar laut samudra dalam yang menimbulkan permasalahan bagi AS dan beberapa negara industri maju lainnya. Ketentuan-ketentuan yang dimaksud adalah yang berisi pengaturan tentang beban pembiayaan bagi negaranegara peserta, pelaksanaan fungsi dari enterprise (perusahaan), prosedur pengambilan keputusan, mekanisme untuk mengadakan peninjauan kembali terhadap Bab XI, persyaratan alih teknologi kepada enterprise dan negara-negara berkembang, pembatasan jumlah produksi mineral dari dasar laut samudra dalam, bantuan ekonomi, dan syarat-syarat keuangan dalam kontrak serta masalah-masalah finansiil lainnya.?

The Agreement Implementing Part XI of the Convention on the Law of the Sea.

5UN Doc. AVRes/48/263, 17 August 1994.

${ }^{B}$ Ketika pada tahun 1980 terjadi peralihan pemerintahan dari Jimmy Carter, yang berasal dari Partai Demokrat, kepada Ronald Reagan, seorang republikan, pemerintah baru AS tersebut telah berhasil didesak oleh para pendukung perusahaan pertambangan AS (yang telah menyumbangkan dana untuk membiayai kampanye Reagan) untuk mundur dari percaturan Konferensi, dan tidak turut menandatangani naskah Konvensi Hukum Laut 1982.

7John E. Noyes. "International Law of the Sea." International Lawyer. Vol. 31. 1997. HIm. 704. 
Pembiayaan bagi Negara-negara Peserta

Sejak tahun 1985 telah dicapai kesepakatan melalui. Preparatory Commission (Prepcom) : 8

... the future Authority should be effective, viable, efficient and cost-effective, and that the structure of the Authority should be lean, at least in the initial stage.

Dalam perjanjian implementasi prinsip "const-effectiveness" ini dimunculkan kembali, dan dijadikan aturan untuk pembentukan segala organ dan lembaga-lembaga penunjang lainnya yang ditetapkan oleh Konvensi. Prinsip yang sama akan diterapkan juga terhadap frekuensi, jangka waktu dan penjadwalan pertemuan-pertemuannya. Pendirian lembagalembaga tersebut akan dilakukan secara bertahap dengan memperhatikan kebutuhan.

\section{Pelaksanaan Fungsi dari Enterprise}

Inti perbedaan pandangan antara negaranegara berkembang dan negara-negara maju terhadap enterprise sebagai badan usaha penambangan dasar laut samudra dalam adalah bahwa, di satu fihak negara-negara berkembang menganggapnya sebagai media untuk mewujudkan prinsip warisan bersama umat manusia (common heritage of mankind). Di lain fihak negara-negara industri maju melihatnya sebagai pesaing terhadap badanbadan usaha serupa yang telah ada, dan menganggap bahwa sebagai suatu badan usaha enterprise harus ditinjau kembali fungsinya dan harus dipaksa untuk mengikuti mekanisme pasar.

Dalam perjanjian implementasi ditetapkan bahwa enterprise akan melaksanakan tahap awal usahanya melalui usaha patungan, dan para mitra usahanya (kontraktor) tidak perlu dihadapkan pada kewajiban untuk melaksanakan alih teknologi. Selain dari itu disepakati juga bahwa tidak akan ada kewajiban bagi setiap negara peserta untuk turut menanggung beban pembiayaan wilayah penambangan yang diperuntukkan bagi enterprise, demikian juga dalam hal usaha patungan. Kewajiban demikian dianggap menyulitkan bagi semua negara peserta baik itu negara maju apalagi bagi negara-negara berkembang.

\section{Prosedur Pengambilan Keputusan}

Masalah pengambilan keputusan ini dapat dianggap sebagai masalah inti dalam perundingan kembali Konvensi Hukum Laut 1982. Negara-negara maju, khususnya AS menganggap bahwa prosedur pengambilan keputusan sebagaimana tercantum dalam Konvensi tidak menjamin bahwa AS dan negara-negara industri maju lainnya akan memperoleh hak suara untuk dapat mengamankan kepentingan-kepentingannya.

Dalam perjanjian implementasi sistem pemungutan suara diganti oleh suatu sistem baru yang disebut system of chambered voting, yang digambarkan sebagai berikut: ${ }^{9}$

${ }^{8}$ Statement by the Chairman of the Preparatory Commission (LOS/PCN/.19), 1985.

9Section 3 par. 5, lihat juga L.D.M. Nelson, "Some Observations on the Agreement Implementing Part Xl of the Convention on the Law of the Sea, "draft paper diperoleh langsung dari yang bersangkutan oleh penulis. 
...decision on questions on substance, except where the convention provides for decisions by consensus in the Council, shall be taken by a two-thirds majority of members present and voting, provided that such decision are not opposed by a majority in any one of the chambers refered to in paragraph.

Komposisi keanggotaan Council (Dewan) sebagaimana diatur dalam Pasal 161 Konvensi dirubah sedemikian rupa sehingga dicapai suatu keanggotaan yang seimbang dan memungkinkan adanya perwakilan dari negara-negara industri maju. Untuk pemungutan suara ini, Perjanjian Implementasi membentuk dua kamar (chamber) yang terdiri dari: ${ }^{10}$

1. Kamaí l: tèrdiri dari kelompok negaranegara yang dipilih berdasarkan kategori (a) sampai dengan $($.

2. Kamar II: terdiri dari negara-negara berkembang yang dipilih berdasarkan pengelompokkan dalam kategori (d) dan (e).

\section{Alih Teknologi}

Salah satu ketentuan Konvensi, khususnya dalam Bab XI yang dianggap sangat memberatkan bagi negara-negara industri maju adalah adanya kewajiban untuk melakukan alih teknologi kepada baik Enterprise maupun kepada negara-negara berkembang. Berbeda dengan ketentuan tersebut, dalam Perjanjian Implementasi ini alih teknologi tidak diwajibkan, karena ketentuan Pasal 5, Annex III, dinyatakan tidak berlaku. Mekanisme Untuk Mengadakan Peninjauan Kembali Terhadap Bab XI (Review Conference) Ketentuan Pasal 155 Konvensi menetapkan bahwa suatu Konperensi Peninjauan Kembali harus diadakan limabelas tahun sejak tanggal 1 Januari dari tahun produksi komersial yang pertama dimulai, untuk meninjau kembali ketentuan-ketentuan dalam Bab XI dan lampiran- lampiran terkait yang mengatur tentang sistem eksplorasi dan eksploitasi di Kawasan (the Area).

Ketentuan tersebut oleh Perjanjian Implementasi telah dikesampingkan dan konperensi demikian dapat diadakan setiap waktu apabila ada rekomendasi dari Council, sedangkan perubahan terhadap Perjanjian Implementasi dan Bab XI Konvensi tunduk pada prosedur yang ditetapkan dalam Pasalpasal 314, 315 dan 316 Konvensi, dengan syarat bahwa semua prinsip, aturan dan syaratsyarat yang ditetapkan dalam Pasal 155 ayat (2) dari Konvensi tetap dipertahankan.

\section{Pembatasan Jumlah Produksi}

Pembatasan jumlah produksi sebagaimana diatur dalam Pasal 151 Konvensi, oleh sebagian besar negaranegara industri maju dianggap tidak masuk akal (artificial) karena pembatasannya didasarkan pada konsep-konsep pemusatan perencanaan ekonomi yang usang dan sudah tidak digunakan lagi oleh banyak negara.

${ }^{10}$ Sama dengan kategori-kategori yang tercantum dalam Pasal 161, tetapi dengan beberapa perubahan substantif. 
Dalam Perjanjian Implementasi ketentuanketentuan yang termuat dalam Pasal 151, khususnya ayat 1-7 dan 9 dinyatakan tidak berlaku. Ketentuan-ketentuan tersebut diganti dengan sejumlah ketentuan umum tentang produksi, yang antara lain menetapkan bahwa:11

1. Tidak akan ada subsidi untuk kegiatankegiatan di Kawasan;

2. Tidak akan ada perlakuan yang berbeda terhadap bahan-bahan tambang yang diperoleh dari Kawasan dengan dari sumber-sumber lain; dan

3. Ketentuan-ketentuan GATT dinyatakan berlaku untuk kegiatan-kegiatan di Kawasan.

\section{Bantuan Ekonomi}

Karena penambangan di dasar laut samudra dalam merupakan penambangan yang akan memerlukan modal dan teknologi yang mahal, dirasakan perlu untuk menetapkan beberapa ketentuan umum yang dapat dijadikan landasan kebijakan bagi Otorita untuk membantu negara-negara berkembang penghasil mineral yang sama dari daratan (land based producers), yang mungkin akan terpengaruh oleh penambangan di dasar laut samudra dalam.

Melalui Perjanjian Implementasi ini akan dibentuk suatu dana bantuan ekonomi yang diambil dari dana administrasi Otorita, yang jumiahnya melebihi biaya administrasi yang diperlukan. Dana tersebut akan digunakan untuk membantu negara-negara produsen tersebut di atas, melalui kerjasama dengan badan-badan pembangunan global maupun regional.

\section{Syarat-syarat Keuangan dalam Kontrak}

Masalah ini merupakan salah satu dari sekian masalah yang menghambat peratifikasian Konvensi oleh negara-negara industri maju. Syarat-syarat keuangan tersebut dianggap sangat membebani para kontraktor karena ditetapkan tanpa memperhatikan bahwa penambangan di dasar laut samudra dalam menyangkut risiko jangka panjang serta biaya pengembangan yang tinggi.

Ketentuan Pasal 13 ayat (3) - (1)0 dari Annex III Konvensi dinyatakan tidak berlaku lagi. Sebagai penggantinya ditetapkan melalui sejumlah ketentuan umum yang dianggap adil baik bagi kontraktor maupun Otorita. Persyaratan keuangan akan disesuaikan dengan sistem yang berlaku pada produksi mineral yang sama di daratan.

\section{Pembentukan Komisi Keuangan}

Dalam sidang-sidang Prepcom tampak adanya kesepakatan umum mengenai perlunya dibentuk suatu Komisi Keuangan, dan beberapa usaha ke arah itu telah mulai disiapkan, meskipun masih ada beberapa hal yang belum mencapai hasil akhir.

Dalam Perjanjian Implementasi berhasil dicapai beberapa kesepakatan mengenai komposisi, fungsi dan prosedur pengambilan keputusan dari Komisi ini. Sambil menunggu terkumpulnya dana yang cukup oleh Otorita, keanggotaan Komisi ini akan terdiri dari 15 anggota termasuk didalamnya lima anggota yang berasal dari negara-negara yang memberikan sumbangan keuangan terbesar kepada anggaran belanja Otorita.

\footnotetext{
"Pasal 13 ayat (3), Annex Ill.
} 
Dalam setiap keputusan yang diambil oleh Assembly (Majelis Umum di Otorita) dan Council, rekomendasi Komisi untuk masalah-masalah tertentu harus dijadikan bahan pertimbangan. Pemungutan suara untuk masalah prosedural memerlukan jumlah suara majoritas anggota yang hadir dan turut dalam pemungutan suara, sedangkan pemungutan suara untuk masalah-masalah yang bersifat substantif akan memerlukan konsensus.

\section{Dampak Perjanjian Implementasi terhadap Negara Peserta}

Segera setelah Perjanjian ini mulai berlaku, negara-negara yang menyatakan turut serta secara sementara dan belum menyerahkan piagam ratifikasinya pada tanggal tersebut, dapat melanjutkan keturutsertaannya sampai tidak melampaui batas waktu bulan November 1998, dengan mengajukan permohonan pada Council dari Otorita internasional (International Sea-bed Authority). Sejak itu, negara-negara yang belum meratifikasinya tidak dapat lagi turut serta dalam perjanjian ini. Sampai saat ini, dari sejumlah 14 negara yang memperoleh status sebagai 'pioneer investor', sepuluh di antaranya telah meratifikasi Konvensi Hukum Laut 1982, yaitu Jerman, Jepang, Rusia, Cina, India, Perancis, Belanda, Inggris, Korea Selatan dan Italia, sedangkan empat negara lainnya yang belum meratifikasi Konvensi adalah Belgia, Kanada, Polandia dan Amerika Serikat.

Perjanjian yang mulai berlaku pada tanggal 28 Juli 1996 tersebut dimaksudkan untuk diinterpretasikan dan diterapkan bersama-sama. dengan ketentuan Bab XI Konvensi Hukum Laut 1982 sebagai satu dokumen, khususnya apabila terjadi sengketa dengan ketentuan- ketentuan sebagaimana tercantum dalam Bab XI yang asli. Negaranegara yang meratifikasi Konvensi Hukum Laut 1982 setelah tanggal. 28 Juli 1994, akan langsung terikat oleh ketentuan perjanjian ini. Bagi negara-negara yang telah meratifikasi sebelumnya diberikan kebebasan untuk menentukan pilihannya, melalui pelbagai mekanisme yang disediakan. Di samping itu negara-negara tidak dapat menyatakan terikat oleh ketentuan perjanjian ini tanpa juga menerima Konvensi Hukum Laut 1982.

\section{Otorita Dasar Laut Internasional (International Sea-Bed Authority)}

Sesuai dengan ketentuan Pasal 156, Bab XI Konvensi Hukum Laut 1982, Otorita Dasar Laut Intemasional adalah organ utama di mana negara-negara peserta akan melaksanakan ketentuan-ketentuan Konverisi yang berkaitan dengan penambangan sumberdaya alam dari daerah dasar laut samudra dalam., Otorita ini dilengkapi oleh Majelis. Umum (Assembly), Dewan (Counci), Sekretariat, ${ }^{12}$ serta dua Komisi yang menangani masalah-masalah perencanaan hukum dan teknis, serta: perencanaan ekonomi

Otorita Dasar Laut Internasional yạng bermarkas besar di Kingston, . Jamaica mengadakan pertemuannya. setiap tahunpada bulan Maret dan Agustus. Pertemuan

${ }^{12}$ Pasal 158 ayat (1).

${ }^{13}$ Pasal 163 ayat (1). 
yang kedua diadakan antara tanggal 11-12 Maret dan 5-16 Agustus 1996. Pada pertemuan bulan Maret tersebut Majelis Umum sebagai organ tertinggi dari Otorita ini telah berhașil memilih Satya N. Nandan sebagai Sekretaris Jenderal Otorita yang pertama.

Pada pertemuan bulan Agustus Majelis Umum bersama-sama dengan dewan telah berhasil menyetujui anggaran belanja. Otorita untuk. tahun 1997 sebesar US \$ 4.15 juta. Dalam pertemuan di bulan yang sama Dewan juga telah berhasil menyepakati Rules of Procedure-nya dan memilih Lennox Ballah, wakil dari Trinidad dan Tobago, sebagai. Ketua Dewan. Juga pada pertemuan tersebut telah berhasil dilantik 22 orang anggota Komisi Hukum dan Teknis.

Satu hal lain yang berhasil dilakukan oleh Majelis Umum Otorita tersebut adalah disepakatinya suatu prosedur untuk memperpanjang keanggotaan pada Otorita, dari negàra-negara dan entitas-entitäs lain yang belum meratifikasi konvensi. Keanggotaan ini bersifat sementara dan hanya diperpanjang sampai tanggal 16 November 1998.

Pada pertemuan tahun 1997 agenda persidangan meliputi masalah pengesahan rencana kerja untuk melaksanakan eksplorasi yang diajukan oleh tujuh dari keseluruhan 14 yang telah disahkan sebagai pioneer investors. Untuk pertama kalinya eksplorasi di dasar laut samudra dalam akan dilaksanakan berdasarkan ketentuan konvensi hukum laut 1982, melalui suatu kontrak eksplorasi antara para kontraktor dengan Otorita untuk jangka waktu 15 tahun. Para kontraktor tersebut terdiri dari pemerintah atau warganegara yang berasal dari India, Perancis, Jepang, Federasi Rusia, Cina dan Korea, serta suatu organisasi yang beranggotakan negara-negara yang berasal dari blok Eropa Timur dan Kuba.

Para kontraktor ini, seperti misalnya Badan Illmu Pengetahuan dan Teknologi Jepang (Japan's Science and Technology Agency) memprediksikan bahwa secara praktis teknologi untuk menambang nodul mangan akan siap pada tahun 2010. Dua kapal eksplorasi Cina akan mulai melakukan eksplorasi di suatu wilayah penambangan di Pasifik Utara dengan menggunakan robot yang mampu untuk dioperasikan pada kedalaman 6000 meter, sedangkan Amerika Serikat dan beberapa negara peserta lairinya telah mengontrak suatu perusahaan untuk mejlakukan studi tentang dampak penambangan dasar' laut samudra dalam terhadap lingkungan. ${ }^{14}$

Pada bulan November 1997, Majelis Umum PBB telah mensahkan perjanjian antara PBB dengan Otorita Dasar Laut Internasional, tentang hubungan kerja antara kedua lembaga tersebut. Mulai tahun 1998 biaya administrasi Otorita akan ditentukan dan dicarikan berdasarkan perkiraan negaranegara anggota Otorita, termasuk negaranegara anggota sementara (provisional members) yang belum meratifikasi Konvensi Hukum Laut 1982. Sebelumnya biaya tersebut diambil dari anggaran reguler PBB untuk awa!

${ }^{14}$ Perusahaan tersebut adalah Redmond Ocean Systems. Margaret $L$. Tomlison. "Recent Development in the International Law of the Sea." International Lawyer. Vol. 32. 1998. HIm. 604. 
pembiayaan yang meliputi tahun anggaran 1994 hingga 1997.

\section{Simpulan}

Dicapainya Perjanjian Implementasi tersebut di atas, menunjukkan bahwa sebagai usaha untuk memberi kekuatan mengikat terhadap ketentuan-ketentuan yang telah dicapai dalam Konvensi Hukum Laut 1982, negara-negara peserta Konferensi Hukum Laut ke III, telah menyadari sulitnya untuk melaksanakan ketentuan-ketentuan hukum yang dicapai melalui kompromi, sehingga pada akhirnya diperlukan suatu kompromi baru.

Hal tersebut juga sekaligus menunjukkan bahwa kekuatan mengikat Konvensi Hukum Laut 1982 tidak hanya ditentukan oleh jumlah ratifikasi yang dicapai, akan tetapi lebih pada negara-negara mana saja yang telah meratifikasinya. Ketika dicapainya jumlah ratifikasi oleh 60 negara sebagaimana yang disyaratkan oleh konvensi, sedikit sekali negara-negara maju yang tergabung kedalamnya. Apalah artinya kesepakatan internasional yang telah dicapai, kalau pelaksanaannya sangat bergantung pada negara-negara yang menguasai ekonomi dunia.

\section{Daftar Pustaka}

Nelson, L.D.M.. "Some Observations on the Agreement Implementing Part XI of the Convention on the Law of the Sea." draft paper diperoleh langsung dari yang bersangkutan oleh penulis.

Noyes, John E. "International Law of the Sea." International Lawyer. Vol. 31. 1997.

Tomlison, Margaret M.. "Recent Development in the International Law of the Sea." International Lawyer, Vol. 32. 1998.

United Nations Convention on the Law of the Sea. 1982.

The Agreement Implementing Part Xl of the Law of the Sea. UN Doc.A/Res/48/263. 17 August 1994.

Statement by the Chairman of the Preparatory Commission (LOS/PCN/L.19). 1985. 